\title{
SHADOW BANKING AS SEEN FROM A BEHAVIOURAL AND NEOCLASSICAL FINANCE PERSPECTIVE
}

\begin{abstract}
Money is not merely a highly exchangeable commodity or the symbol of value established in exchange by utility-seeking individuals. Private money is a value sui generis that is established by reactions between issuers-shadow banking and users of money. These relations can be explained by the behavioral theory of finance and neoclassic theory of finance.

Shadow banking and classical banking relations are characterized by the relations of both cooperation/trust and conflict/struggle, which give private money its value and produce the alternating phases of order and disorder.

If the link between the public and the private sector is to be bypassed or severed, should this be seen as an exceptional emergency measure or the first step in radical structural change in the social relations for the production of money? The Neo-institutional answer on this question is that the shadow banking is now in the first phase of its institutionalization. Shadow banking is a fundamental and systemic financial innovation. It encompasses all financial activity, except traditional banking, which requires a private or public guarantee and backing to operate.
\end{abstract}

Key words: shadow banking, behavioral finance, private money.

\section{INTRODUCTION}

The events of the GFC in the years following 2007 have led to an increased interest in and research into ,shadow banking". This phenomenon can be analysed from the perspective of behavioural finance as well as from that of neoclassical finance. In the first case we refer to the semantics of the word „shadow" and in particular it's meaning of a ,shelter" or "sheltering". In this case, ,shadow banking" amounts to the principle of upholding banking secrets under the conditions of an uninhibited flow of capital, in an environment of a digital and telecommunications revolution. In the second case, shadow banking is seen as issuing money in parallel to money issued by (the institution of) a central bank. Demand for money anchored in public and private debt is strong enough that it stimulates money supply and leads to the lowering of the price of money for selected participants of financial markets. Shadow banking,

* Ph.D. hab., Full Professor at The Academy of Social Sciences, Chair of Banking and Insurance Department. 
as finance existing in parallel with a deposit-credit-based one and another lead by central banks, has its grounding in both theories of finance. On the one hand this is a rational economic activity, seeking to lower transaction costs and provide cheaper money; on the other it is a practice of hiding money away from a third party's prying eyes.

This essay aims to juxtapose and critically evaluate shadow banking in the context of some of the theoretical paradigms of both behavioural and neoclassical economics. The effect of this comparison should be to elevate the methodological identity of the institutional theory of finance, which constitutes the mainstream of the modern theory of finance.

\section{2. „SHADOW BANKING” IN ITS BEHAVIOURAL FINANCE PERSPECTIVE}

Figure 1 provides a schematic summary of the different definitions of and perspectives on shadow banking, which can be broadly defined as credit intermediation outside the conventional banking system. Shadow banking can complement traditional banking by expanding access to credit or by supporting market liquidity, maturity transformation, and risk sharing. Shadow banks often enhance the efficiency of the financial sector by enabling better risk sharing and maturity transformation and by deepening market liquidity.

However, the global financial crisis revealed that, with the absence of adequate regulation, shadow banking can put the stability of the financial system at risk in several ways.
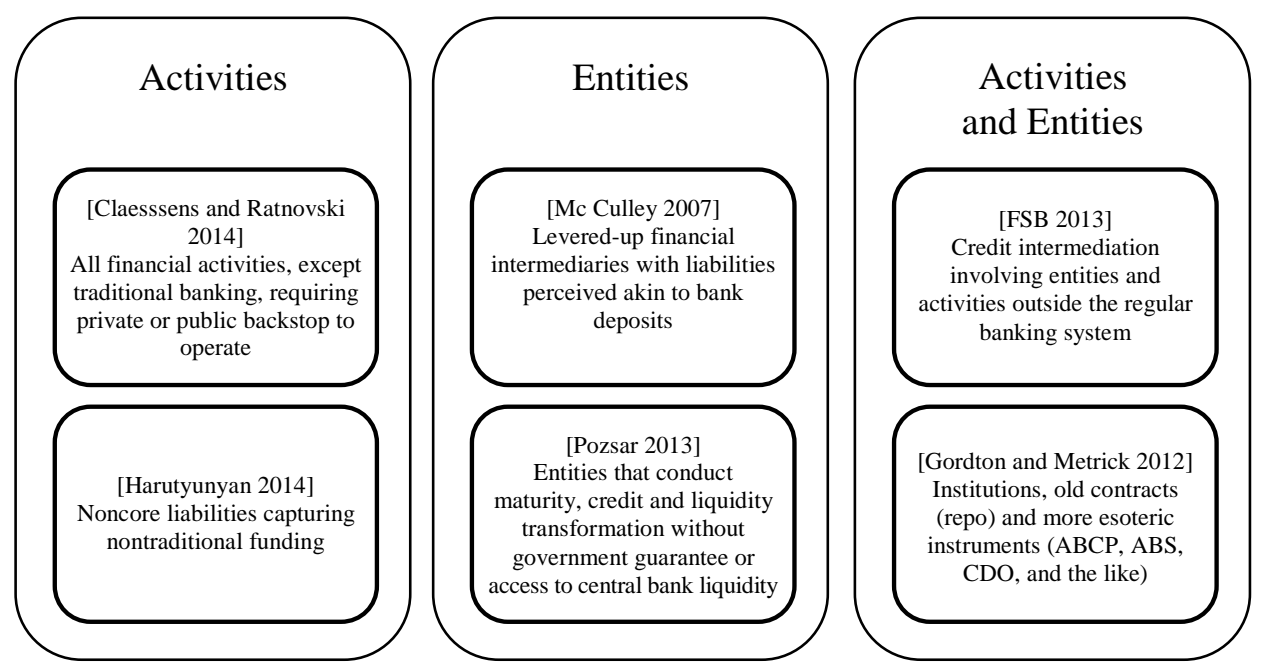

Figure 1. Different Definitions of Shadow Banking

Source: Financial Stability Report [2014], International Monetary Fund, October [2014: 91]. 
The behavioural paradigm of science arose from the desire of social scientists and humanities researchers to be able to conduct precise and controlled experiments in the same way as they were practiced in physical sciences. In this paradigm there was a stimulus and the reaction of the object under consideration and this, combined with the feedback loop, created a relatively isolated circuit. In the middle of this behavioural paradigm stands the „Black Box", an imaginary object, which reveals it nature through its reactions to controlled stimuli and monitored behaviour. A researcher learns about the nature of a researched object through these reactions in response to controlled inputs. In these kinds of experiments there was no need to take account of either human influences or an array of human instincts. Researchers did not have to assume a priori what constituted the nature of men or mice. It was enough to determine a register of punishments and rewards in conjunction with their sequence in time. Reinforcement of certain behaviours and the elimination of others allowed for the learning of behaviours which were recognised by an experimenter as desirable. In this way it became possible to stop arguing about the ,true" nature of a man. Is it a man of an organisation, or a man of an institution? Is it a social man, or an economic man, or a man of money? Each of these types of man associates an input with an output in a specific way. One social technique from the behavioural stream has gained a scientific basis for its development. It is the findings of the behavioural stream of social sciences concerning the discovery of habits. Habits get formed as the brain constantly seeks ways to limit effort. Key habits include, among others, discretion in financial matters.

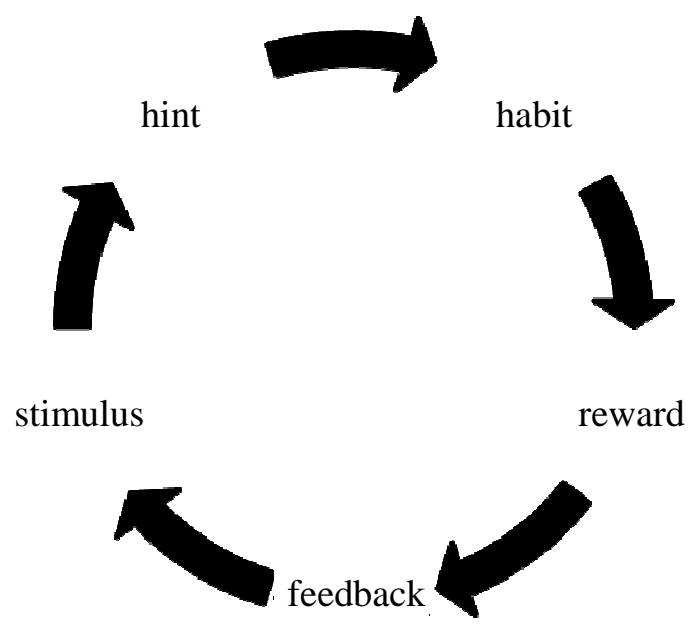

Figure 2. Formation of habit

Source: Jan K. Solarz original material - based on C. Duhigg [2013]. 
The impulse for discretion about financial matters developed when usury was forbidden. For instance, usury was met with a different response in Northern Italy, both by the guild of goldsmiths, and the Jewish community in Venice, who had a concession for banking services from the Venetian authorities. In the first case, the response was that all matters associated with money had to be documented in writing. Only agreements in writing were considered valid, as they could be verified by their conformity with the law of the guild. In the second case, a different rule was adopted; that verbal communication was more important than written. The latter could be changed depending on the external circumstances. (Verbal communication does not get changed under the sanction of losing trust.) Dealing with money relies on trust.

What gave rise to these contrasting responses to the same stimulus; the increased penalty for usury, was the different social structure of the goldsmith's guild on the one hand and of the Jewish community on the other. The guild had a strongly hierarchical structure with the master, apprentices and students not connected together by religion or blood ties. The Jewish community however had an egalitarian character and was united by religious faith and kinship. Jewish rabbis were in a position to adjudicate in all sorts of disputes between the community members, and the fear of eternal condemnation was strong enough to preclude any false testimonies from opposing parties. (In the guild, papers had to be in order and there could be no problems with the authorities controlling the quality of the coins used by merchants in the market.) If counterfeit coins were discovered the penalty could be a beheading in the town square.

In the seventeenth century there was a split between the banks of ,public trust" and those of ,private trust". The first category applies to universal banks and was based on the trust in the bank's records, bookkeeping and trusteeship. The second category included investment banks and was based on the investor's interest in the bank as a financial intermediary as well as a substitute investor in the financial instruments, with the rate of return on investment as the reward.

Nowadays, all the banks trading risk are averse to holding that risk and accepting it as their own liability. Relationship-based banking is being replaced by banking focused on transactions. The natural monopoly of the banks as financial intermediary is undermined by all sorts of bank substitutes, such as various state agencies, deposit outlets, as well as investment funds with market certificates. The old practice of actually having faith in the institutions of public trust has to be now replaced by a rule of limited trust.

The evolution of banking under the influence of its customers' habits is presented in Table 1. 
Table 1. Change in banking under the influence of its clients

\begin{tabular}{|c|c|c|}
\hline Habits & Passivity in financial matters & Activity in financial matters \\
\hline \hline Avoiding losses at all cost & Relationship-based banking & Transaction-based banking \\
\hline Risk acceptance & Trusteeship banking & Parallel banking \\
\hline
\end{tabular}

Source: Jan K. Solarz, original material.

Transactional banking and parallel banking are like conjoined twins. What they have in common is the pressure from the suppliers of capital for an ever-greater rate of return from that capital. (Parallel banking is often specialized and hidden from a wider audience by another form of gaining profits through banking based on deposit taking and credit.) Trusteeship banking and parallel banking are thus two essentially different concepts of financial mediation. In the first model of banking, the goal is to uphold the value of the entrusted assets for a sufficiently long time. In the second model, the goal is to supply instruments suitable for managing risk in the short-term. Sometimes this is only microseconds but is still enough time to speculate on electronic forex markets. The substitution of bank deposits with obligations issued by investment funds, amounts to a break from the monopoly of the central bank to issue money. The external consequences of this phenomenon manifest themselves in the greater fragility of the financial system, it being more prone to panic and also in its increased appetite for financial risk.

The process of the homogenisation of the financial markets leads to their greater fluidity but also to a greater sensitivity to distortion and turbulence. The existing buffer absorbing market risk is rapidly diminishing, with emotions playing an ever-greater role. Economic theory is being extended by new terms such as aversion to risk, decisions under the influence of emotions, post-decision regret, hyperbolic discounting and subjective assessment of probability [Opolski and Potocki 2013: 37].

A key question leading to an insight into parallel banking and the supply of „private" money, is, why is this money so readily accepted? Usually all alternative (,private") forms of money encounter barriers such as:

- Limited acceptance, difficulty in reaching a critical mass, low networking effects.

- Insufficient trust in regard to the issuer of the money and the rules under which this money is issued [Górka 2013: 29].

Parallel banking was dependent on, and developed together with, trust in licensed financial intermediaries. Conversely, it shrank when trust in official financial intermediaries was diminished. Despite these pro-cyclical swings, parallel banking maintains its critical mass. One explanation for this phenomenon may be the ways of making use of this cash. The financial 
instruments used by parallel banking display for its wide number of users some of the distinctive traits of cash; they are anonymous and fluid. The transactional costs of their use are similar to those of cash. A broad influx of liquidity linked to „repo" operations guarantees access to midday credit and ensures the liquidity of the obligations of investment funds. The sheer scale of securitisation transactions also acts in favour of maintaining trust in the intermediaries using this quasi-money.

An alternative behavioural explanation of this demand for parallel banking services is that it is a flight to safe havens from financial losses. Faith in the existence of financial assets free from risk attracts customers to parallel banking. Its agents are ready to incorporate and accept the actual risk of ,safe" financial assets, while being sure that they can count on access to financial markets under the conditions of the low interest rates provided by the central bank [Perotti 2012]. „The rate free from risk can be defined in a functional way as an interest rate which covers the premium for [Niedziółka 2009: 406]:

- withholding immediate consumption

- actual and expected inflation

- an interest rate risk".

\section{SHADOW BANKING AS SEEN FROM A NEOCLASSICAL PERSPECTIVE}

According to the classical economic tradition, an increased supply of money under the condition of the fixed demand for that money results in lowering its cost. The neoclassical theory observes that transactional costs shift to the point of price equilibrium. Lower transactional costs are equivalent to the higher efficiency of the markets.

In the centre of the neoclassical theory of finance stands economic rationalism. The demand for parallel banking services is not irrational, when there are financial intermediaries, who perform the same service as institutions supplying credit but cheaper, why not make use of their services? Even more so when, after a detailed analysis, one learns that the companies who are sub-ordinate to the licensed banks perform parallel banking in Europe.

A point of departure in classical finance theory is the three-way interdependence between fluidity, rate of return and security in the management of risk arising from financial mediation. There is no way to maximise all of these three objectives at the same time. If an intermediary is a „Monetary Financial Institution" then it has to be subject to supervision in terms of its ability to manage its fluidity and to take on the risk of the loss of fluidity by the party of any given transaction. A particular danger arises from the lack of sufficient limitations in managing the risk of the entrusted assets [Szpringer 2013: 37]. 
(The security of a financial system is ensured when a given risk finds its cover in the same capital). If there is legal arbitration or it comes down to a conflict of legal norms then, sooner or later, the lack of security in business trading will be exposed. For this reason, many specialists have come to the conclusion that para-banking finds itself at the core of parallel banking, and thus are financial intermediaries who are not regulated or even supervised.

The proposition that parallel banking is hidden away from regulation and supervision is only partially true. Many regulatory solutions and supervisory actions affect parallel banking either directly or indirectly. This is predominantly so in regard to customer protection. The special regulations of customer credit or mortgage lending extend to parallel banking. However, retail banking, even of a private banking variety and even in China, does not constitute the core of private banking. A global financial institution of systemic importance occupies this position.

What makes the difference between the licensed banking of a deposit-credit variety and parallel banking is the use by parallel banking of the functional equivalents of deposits and the issuing of private money. This money goes to international corporations, wealthy households and the small and medium-sized businesses. Private banking clients have become the creditors of state and local authorities.

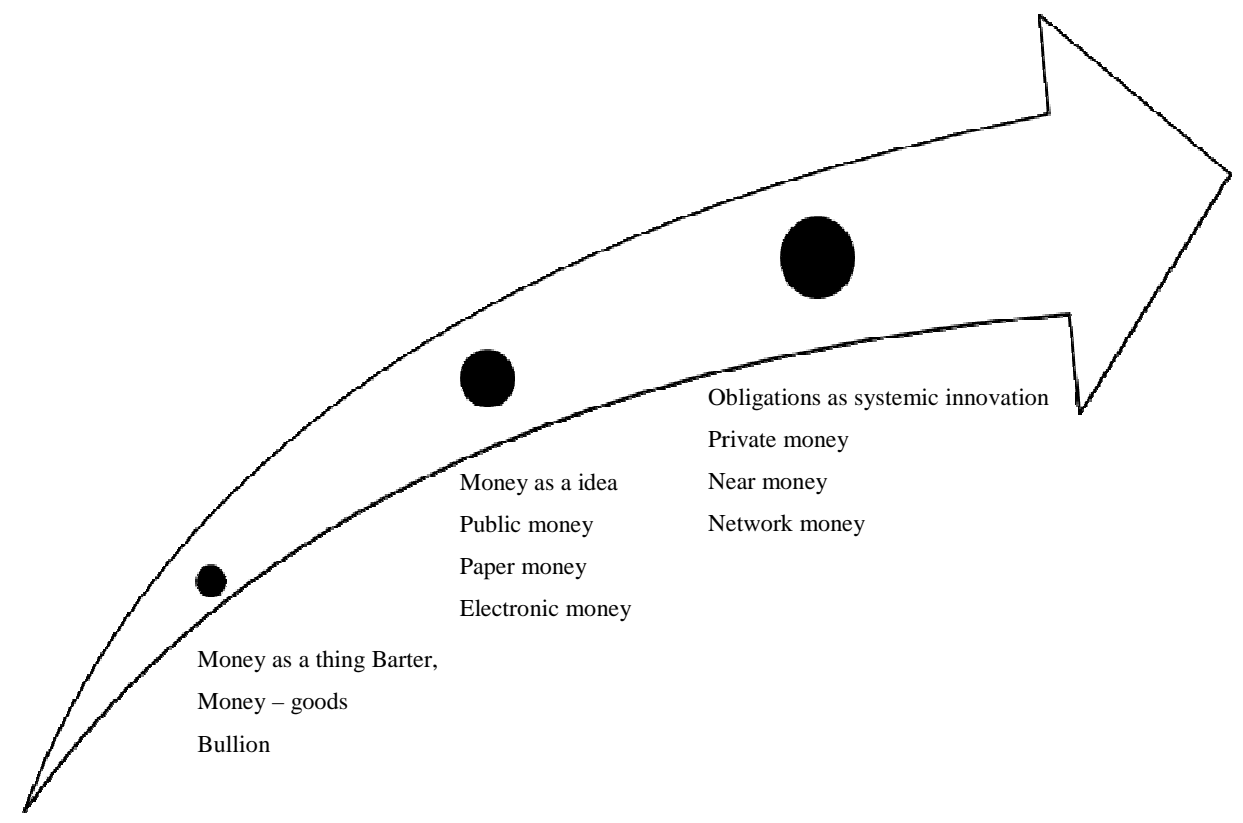

Figure 3. Phases of the Development of Money

Source: Jan K. Solarz - own material. 
Whereas money based on bullion had high transactional costs, these costs were significantly lowered by „electronic" money. Money generated against short-term non-banking financial institution obligations is today the cheapest money in terms of transactional costs, access and price. A strong, effective demand for parallel money requires that the balance of gains and losses be assessed in the aftermath of introducing this systemic innovation as well as taking into account the external costs of its existence.

When one of the market participants has soft financial limitations, the other party has to have them firmer. In the case of money based on bullion, the monetary authorities ensured that the ruler's monopoly on falsifying coins was observed. In the case of money based on credit and paper money, excessive issuing led to inflation, an illicit tax imposed by the devaluing currency. State authorities and the central banks have resorted many times to issuing money to stimulate the economy. Money supply based on debt leads to a polarisation of the economy and society. On the one hand it leads to an excessive development of the financial sector and on the other to stagnation in the real economy. The beneficiaries of the issuing of money based on export savings are international corporations, the state fiscal authorities and wealthy citizens. The victims of soft financing include resident tax payers, who cannot but accept increased financial support for financial institutions deeply connected to global markets and who, in effect, are ,too big to fail” [Gruszecki 2013].

Parallel banking gains in strength when the market is constrained by limitations, e.g. high interest rates for deposits or unjust rates of credit when the risk premium falls. Parallel banking shrinks when the financial markets are in a state of uncertainty and when there are disturbances in its functioning, meaning parallel banking has an extremely pro-cyclical character [Duca 2014].

\section{SHADOW BANKING FROM A NEO-INSTITUTIONAL PERSPECTIVE}

The private banking phenomenon is explained differently in the behavioural and neoclassical schools of the theory and practice of finance. Behavioural finance explains the rise of parallel banking by the difference in the culture of investment banking and deposit-credit banking. External market pressure for a decent rate of return on capital has initiated a process of the convergence between both cultures into one of transactional banking.

The global lack of equilibrium as a consequence of free capital flows and financial sector deregulation has led to a flight of wealthy individual and institutional investors into secure financial assets. A decade of dynamic economic change and the faith in unlimited growth of real estate prices sooner or later had to cause the emergence of the Minsky momentum. According to the Minsky momentum, a long period of prosperity has thrown the global 
financial equilibrium ever farther out of balance. The two competing narratives about what has happened to the global financial system and why parallel banking plays such a significant role have been linked together by the neo-institutional school of thought. This approach has adopted from the findings of behavioural finance the proposition that cultural roots and habits play a hugely important role in the functioning of contemporary financial markets. On the other hand, it took from neoclassical heritage the awareness that equilibrium in the financial system has a dynamic rather than a static character [Sum and Jessop 2013], leading to the key role of trust in understanding the parallel banking phenomenon.
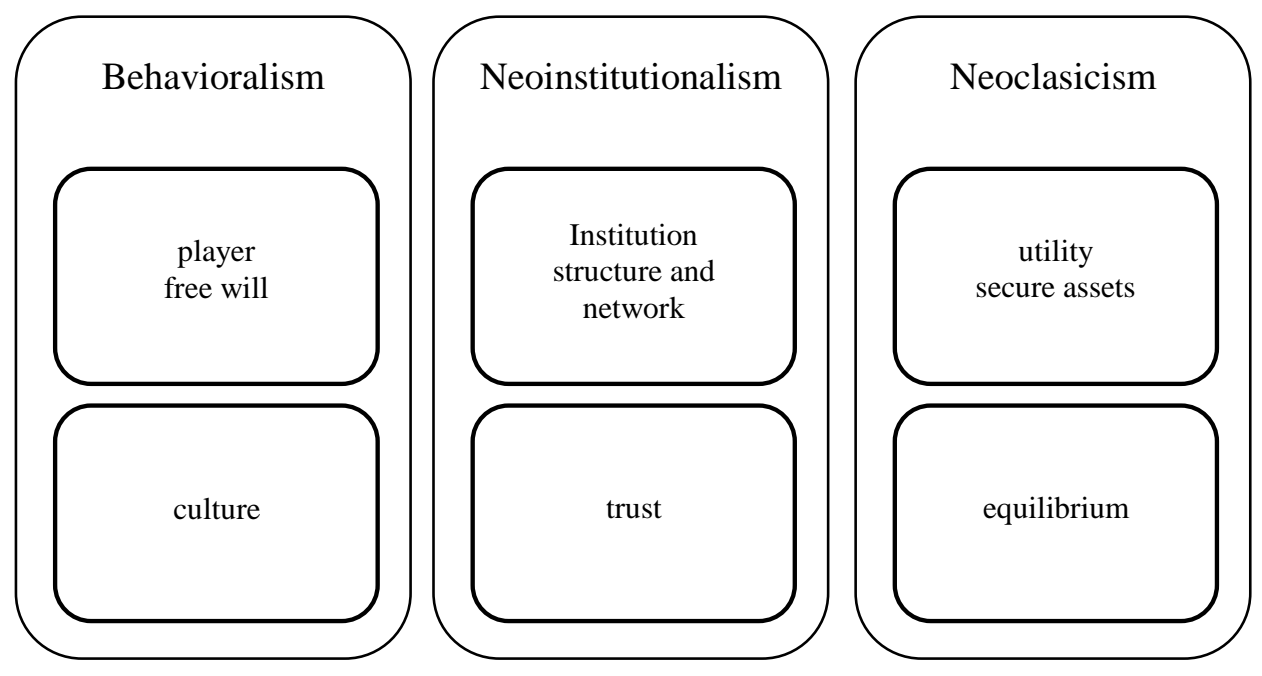

Figure 4. Neo-institutionalism as a bridge linking behavioural and neoclassical schools of finance theory

Source: Jan K. Solarz - own material.

Trust amounts to a wager that an agent will behave in accordance with the expectations of the principal. Institutional trust is characterised by professional standards, ethical rules and systems of certification - and it does have an impersonal character [Wierzbiński 2009: 32]. Trust allows for the predicting of people's behaviour. This is a win-win game. Trust lowers the transactional costs. Trust requires reciprocity. Trust is harder to build than to lose.

While some institutions build trust, others destroy it. Parallel banking attracts people and business entities that are otherwise excluded from access to professional financial risk management, which is why parallel banking is often perceived of as a grey, informal part of the economy. The critics of parallel banking see it as a parasitic institution attaching itself to the healthy, regulated and supervised system. Such a view is far removed from the reality. It is formed 
as an answer to social and political concerns and in order to find a guilty party for the unhappy situation at hand. When the decision makers in deposit-credit banking or parallel banking do not take into account in their economic calculations the external costs of their actions then they, in fact and in equal measure, contribute to the increased risk in the financial system. Research into public opinion over the question of trust in financial institutions makes it clear that trust is particularly sensitive to the level of bonuses paid from profit and awarded to the top management executives of financial institutions. The public's trust is then affected by reports in the media but also by the fall of banking stocks on stock exchanges. Against expectations, Holland's nationalization of banks did not lead to a loss of confidence in the banks. A more significant factor was the personal loses of the respondents during the GFC in 2007 onwards [Jansen, Mosch and Cruijsen 2013].

\section{REFERENCES}

Claessens S., Ratnovski L., 2014, What Is Shadow Banking?, IMF Working Paper 25.

Duca J. V., 2014, What Drives the Shadow Banking System in the Short and Long Run?, DALLASFED Working Paper 1401.

Duhigg C., 2013, Siła nawyku, Wydawnictwo Naukowe PWN, Warszawa.

Financial Stability Board, 2013, Global Shadow Banking Monitoring Report 2012, Basel.

Gorton G., Metrick A., 2012, Securitized Banking and the Run on Repo, Journal of Financial Economics 104(3), 425-451.

Górka J., 2013, Efektywność instrumentów płatniczych $w$ Polsce, Wydawnictwo Naukowe Wydziału Zarządzania Uniwersytetu Warszawskiego, Warszawa.

Gruszecki T., 2013, Współczesne problemy pieniqdza papierowego, In: J. J. Bednarczyk, M. Sobol (eds.), System finansowy wobec wyzwań rozwojowych, Spatum, Radom.

Hartwell C. A., 2014, The Impact of Institutional Volatility on Financial Volatility in Transition Economics: A GARCH Family Approach, Moscow.

Harutynyan A., Loukaionova E., Walton R., Korniyenko Y., Amidzic G., Sanab H. Abu, Shin H. S., 2014, Shedding Light on Shadow Banking, IMF Working Paper 10.

Jansen D. J., Mosch R. H. J., Cruijsen C. A. B., 2013, When Does the General Public Lose Trust in Banks?, DNB Working Paper 402.

McCulley P. A., 2007, Teton Reflections, Global Central Bank Focus Series, PIMCO, September.

Niedziółka P., 2009, Kredytowe instrumenty pochodne a stabilność finansowa, SGH Monografie i Opracowania 563.

Opolski K., Potocki T., 2013, Pojecie racjonalności w naukach ekonomicznych z perspektywy ekonomii behawioralnej, In: I. Bludnik, M. Ratajczak, J. Wallusch (eds.), Ekonomia. Teoria, historia, praktyka, Wydawnictwo Uniwersytetu Ekonomicznego w Poznaniu, Poznań.

Perotti E., 2012, The Roots of Shadow Banking, Duisenberg School of Finance Policy Paper 24.

Pozsar Z., Tobias A., Ashcraft A., Boesky H., 2013, Shadow Banking, Economic Policy Review $19(2), 1-16$.

Schwarcz S. L., 2012, Regulating Shadow Banking, Review of Banking \& Financial Law 31(2).

Szpringer W., 2013, Shadow banking jako nowy obszar regulacji prawnej, Monitor Prawa Bankowego 6. 
Jan K. Solarz

\section{BANKOWOŚĆ RÓWNOLEGŁA W PERSPEKTYWIE BEHAWIORALNEJ I NEOKLASYCZNEJ}

Pieniądz nie jest już tylko instrumentem wymiany lub symbolem wartości dla jednostki poszukującej użyteczności. Pieniądz prywatny $\mathrm{z}$ definicji ma wartość ukształtowaną $\mathrm{w}$ toku interakcji miedzy jego emitentem z bankowości równoległej a jego użytkownikami. Shadow banking oraz klasyczna bankowość zostały opisane na dwóch osiach; współpracy/zaufania oraz konfliktu i kooperacji negatywnej. Te relacje nadają prywatnym pieniądzom wartość i przyczynianie się do ładu lub jego braku. Czy powiązania miedzy sferą finansów publicznych i finansów prywatnych powinny być postrzegane jako zjawiska nadzwyczajne czy jako pierwszy krok strukturalnej reformy podaży pieniądza? Neoinstytucjonalna odpowiedź na to pytanie to przeświadczenie, że to jest pierwsza faza instytucjonalizacji shadow banking. Nanofinnse postrzegają bankowość równoległa jako innowację systemową. Finanse behawioralne lokują shadow banking w hybrydowym pośrednictwie finansowym, które łączy w sobie wszystkie czynności bankowe, poza regulowanymi, które wymagają prywatnej lub publicznej sieci bezpieczeństwa.

Słowa kluczowe: bankowość równoległa, finanse behawioralne, pieniądze prywatne. 